\title{
Towards a Refined New Concept of New Urbanism in Egypt
}

\author{
Abeer Elshater \\ Faculty of Engineering, \\ Ain Shams University, 1 Sarayat Street, Cairo, Egypt \\ abeer.elshater@yahoo.com.
}

\begin{abstract}
This paper introduces a method to apply the principles of New Urbanism on an Egyptian neighborhood unit. It extends to their relationship with the common dimensions of urban design. It proposes four objectives: a) Interpret the new concepts of New Urbanism, b) Cite principles of Urbanism and trends emanating from it, c) Discover the structure of the philosophical concept of urbanization and d) Design a matrix inventories the compatibility of the principles of New Urbanism and urban design dimensions. Finally, the matrix tests the combination of the principles and the dimensions in a traditional Egyptian urban fabric, Basilica Church Plaza.
\end{abstract}

Keywords: New Urbanism; Urban Design; Urban Design Dimensions; Behavioral Dimensions; PRAV.

eISSN 2514-751X @ 2018. The Authors. Published for AMER ABRA cE-Bs by e-International Publishing House, Ltd., UK. This is an open-access article under the CC BY-NC-ND license (http://creativecommons.org/licenses/bync-nd/4.0/). Peer-review under responsibility of AMER (Association of Malaysian Environment-Behaviour Researchers), ABRA (Association of Behavioural Researchers on Asians) and CE-Bs (Centre for EnvironmentBehaviour Studies), Faculty of Architecture, Planning \& Surveying, Universiti Teknologi MARA, Malaysia.

https://doi.org/10.21834/aje-bs.v3i8.292 


\subsection{Introduction}

\subsection{Urbanism Today}

In the nineties, urban design and New Urbanism, as a new trend in Urbanism, emerged in synchronization (Duany, 2001). It integrates both of the perceptual, functional and behavioral dimensions with the sustainable environmental ideas. At the present time, the experts in urban design professional practice taking into account the people-related issues as a base to build cities (Carmona, 2010). Notably, this makes livable cities based on design solutions; convenient to the term of quality of life. The ABCs of urbanism is one of the current global trends emanating from the concept of urbanism that has emerged recently to (Artibise, 2010), as a summarizing method. It appears in twenty-six approaches arranged by spelling English letters (Fig. 1). The main thing is supporting the social life to make cities livable.

\subsection{Pressing Global Problem}

Since the beginnings of the twentieth century, the mixed land-use is the main purpose of planning and designing the neighborhood. With the emergence of modern architecture, the dominance was for the car. After the World War II, this trend named as sprawl or conventional suburban development (CSD) (Duany, 2001: 3-18). Researches criticized CSD because of lacking pedestrian priority (Urbanism, 1996:5-10; Duany, 2001). On the other side, many cities suffer from the overcrowding due to the dependence on cars (Panerai, 2004:141-143). The spread of the deteriorated areas that include social groups of low-level of education and ethics comes without any plans for manipulating in the communities of the developing countries. Not only mistiness of the ability of the project investments, but also the architectural character, traffic problems and environmental issues (Gilderbloom, 2005:40; Steuteviller, 2009). Therefore, the New Urbanism came to improve the communities to solve transportation problems in the forefront priorities. It suggests action plans to CSD in order to improve the communities within walking distances.

\subsection{Research Problem and Hypothesis}

Although New Urbanism is for livable cities, but there is an inappropriate use of the principles commensurate with the adequate uses of urban design dimensions. Therefore, the paper suggests a hypothesis addressed as "if each one of the group of the principles of New Urbanism and behavioral dimensions makes a livable city, the integration between both will provide solutions convenience to the quality of life". The paper inventories the principles of New Urbanism inside an Egyptian neighborhood. It extends to their relationship with the common dimensions of urban design. It provides a matrix addressed as "New Urbanism versus urban design dimensions" to be tested upon the case study from the behavioral milieu; it is the most tangible to the principles of New Urbanism.

\subsection{New Urbanism Upbringing}

The principles of New Urbanism started as a movement in urban design in 1980 (Carmona, 2010; Duany, 2001), to improve the pedestrian movement in the neighborhood. It continued 
to grow in the course of reforming the aspects of urban planning. It influenced in areas according to standards of urban design. This theory comes to improve the built environment and fosters the quality of life in safe and pleasant places. It retrieves the notion of citizenries which include various activities within a short walking distance. It drives the citizenries towards the utopian city, within the range of uses, people, forms and meanings (Kelbaugh, 2001).

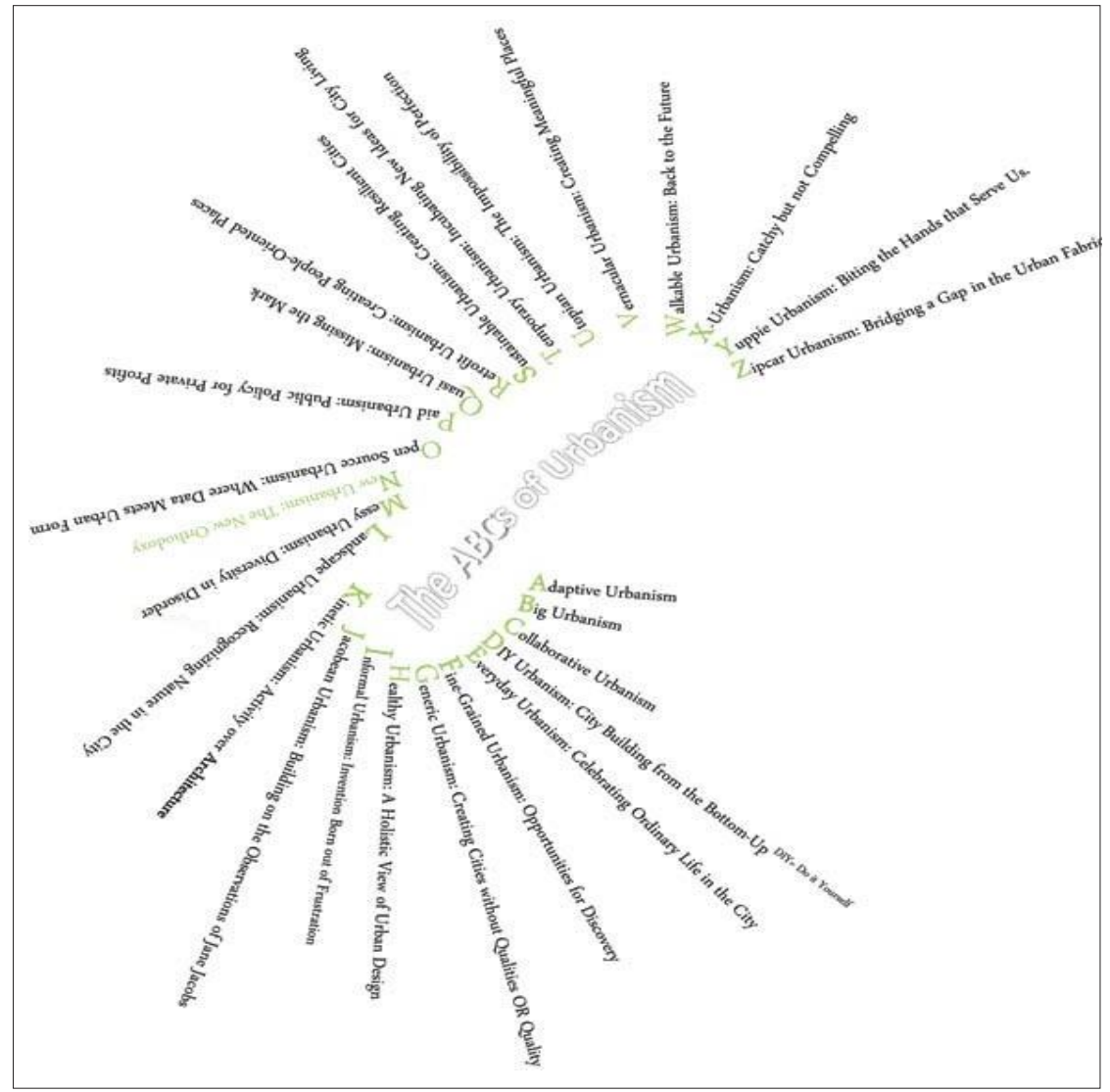

Figure 1: ABC's as a Trend of Urbanism

\subsection{The New Urbanism Principles}

The Charter of New Urbanism Congress (CNU) declared twenty-seven principles (The Congress of New Urbanism, 1996; Taarup, 2000). The principles are nine principles for each one of the region, the neighborhood and the buildings block. The principles declared to guide public policy, development, urban planning, and architecture design. According to a literature review pursued on $\mathrm{CNU}$, the principles of New Urbanism, at the level of the neighborhood, 
modified to be ten principles instead of nine (Carmona, 2010). The ten principles can be listed in five groups (Fig. 3). These are; first, enrich the community to provide choices for pedestrian with various activities for all users. Secondly, the comparability of urban component, thirdly, applying for the urban Infill, fourthly, holds smart transportation of connection. Finally, ensure the quality of life.
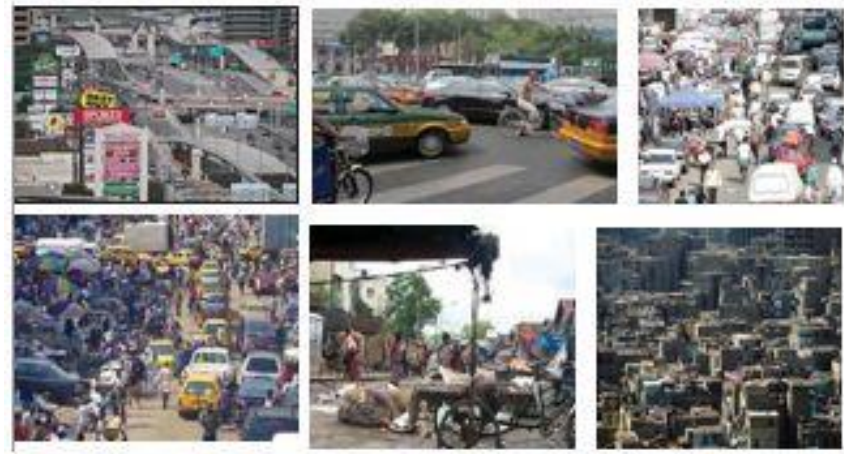

Figure 2: The Urbanization as a Global Problem: (a) the USA; (b) China;

(c) Egypt; (d) Informal Transportation in Developing Countries (United Nations Human Settlements Program, 2009:13); (e) India; and (f) Informal Settlement, Egypt.

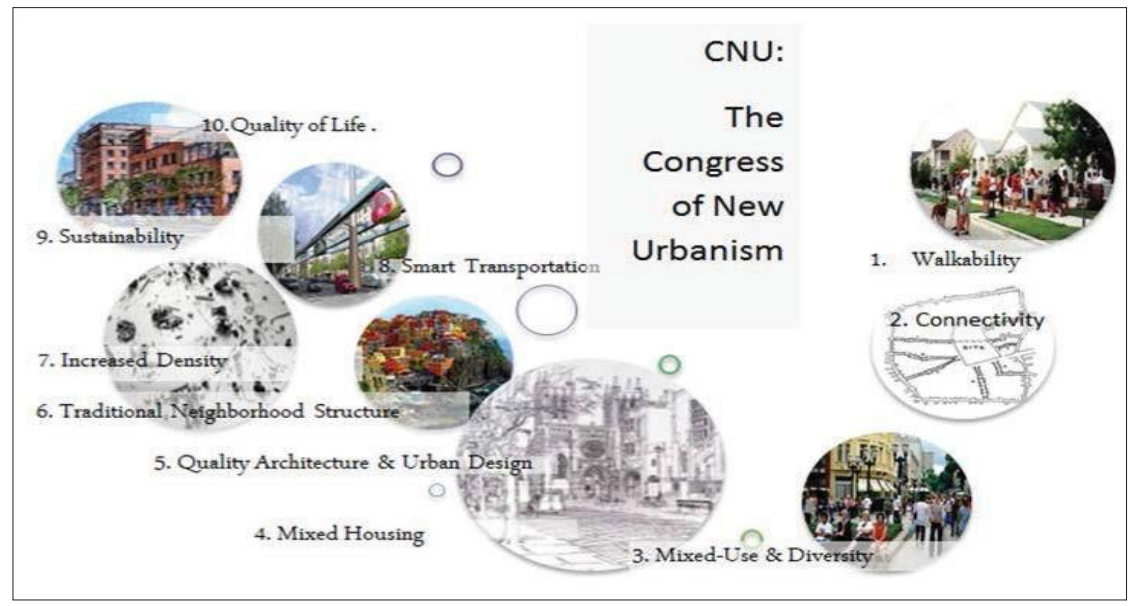

Figure 3: The Principles of New Urbanism from CNU Point of View

\subsection{How Can CNU Applied?}

Some projects adopted the principles of New Urbanism; these are Adelaide and Copenhagen. The developments in Copenhagen followed for turning a car oriented city into a walkable city (Kersi, 2000). The public realm and increased taxes were the most demands 
catalysts for this development. In the city of Adelaide reclaiming, Gehl defines 4 terms to match the New Urbanism trends (Gehl, 2002). These terms are the walkability/connectivity, responsiveness, appropriateness and variety/ robustness (Fig. 4, 5, 6 and 7). The research can classify the principles of New Urbanism, from the point of view of CNU and its implication in Adelaide and Copenhagen, into 4 categories, address as PRAV, Table 1.

Table 1: The Concluded Principles

\begin{tabular}{|c|c|}
\hline \multicolumn{2}{|c|}{ The Term Jis Man Keywords } \\
\hline (P) & 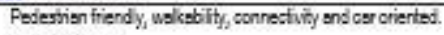 \\
\hline$(\sqrt{2})$ & Resporsiveress. \\
\hline$(A)$ & Aeshebics, sppropristeness and qusity of erchitecture. \\
\hline$M$ & Vsriety and robuatness. \\
\hline
\end{tabular}

\begin{tabular}{|c|c|c|c|}
\hline & CNU & $\begin{array}{l}\text { Copenhagen, } \\
1993\end{array}$ & Adelaide, 2002 \\
\hline 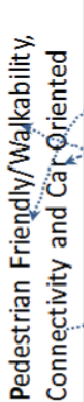 & 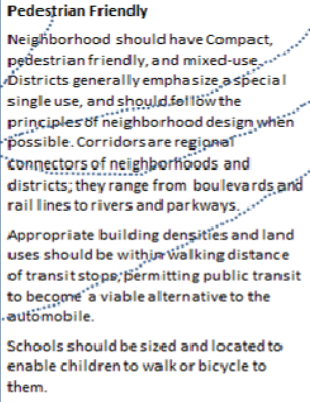 & $\begin{array}{l}\text { Walkability and } \\
\text { Car-Oriented } \\
\text { 1. Converting } \\
\text { street into } \\
\text { pedestrian } \\
\text { and parkingares. } \\
\text { gradually. } \\
\text { 3.Turn publis lots } \\
\text { into publis } \\
\text { square, } \\
\text { 4. Make bicycle } \\
\text { available. } \\
\text { 5.Smart } \\
\text { Transportation }\end{array}$ & $\begin{array}{l}\text { Walkability and Copnectivity } \\
\text { 6.Roorit to walk with dignity, integrity and without } \\
\text { 7.Comfortable climatic conditions } \\
\text { 8. Pleasant facades at street level to stroll alongside and } \\
\text { observe } \\
\text { 9.Good conditions for people with disabilities and prams } \\
\text { 10. Clear structure of pedestrian system } \\
\text { A pedestrian system that connects important destinations } \\
\text { promenade through the city } \\
\text { 11.Good walking rhythm with few interruptions } \\
\text { 12. Many well placed benches. Widespread secondary } \\
\text { seating such as steps and edges of planter boxes } \\
\text { 13. Well-situated cafes and outdoor restaurants } \\
\text { 14. Beautiful and effective lighting. }\end{array}$ \\
\hline
\end{tabular}

Figure 4: This Represents the Interrelationbetweenthe Title Pwith both the $\mathrm{CNU}$, Copenhagen and Adelaide Represented bya Dotted Line (Authorbasedon Gehl, 2002; KersiF,,2000;Evans, 2012)

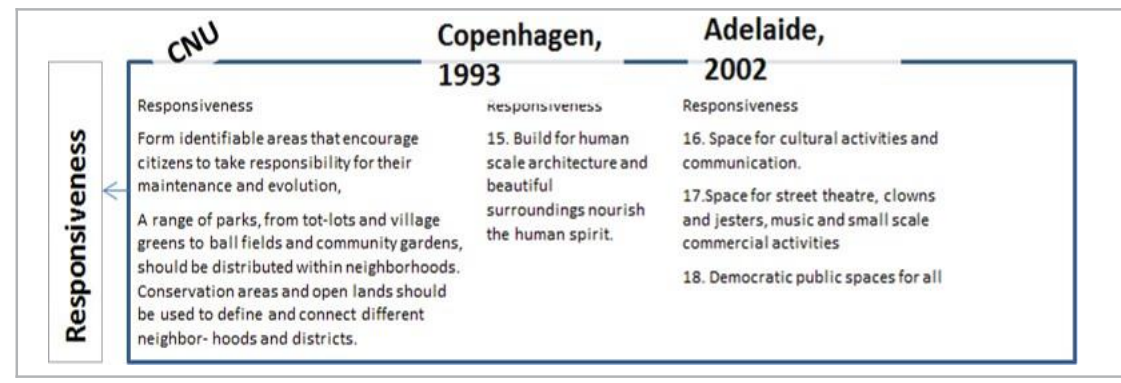

Figure5: This Representsthe Interrelation between the title R with both the CNU, Copenhagen and Adelaide Represented by a Dotted Line

(Source:Ibid) 


\subsection{Urban Design Dimensions}

The urban design through classified documents can be represented in six common dimensions (UDD) (Carmona, 2010). The UDDs are the perceptual, functional, visual, temporal, behavioral and environmental dimension (Banerjee, 2001; Baran, 2003; Bartuska, 2007; Carmona, 2010), Fig. 8. The present study focuses on the criteria of the behavioral dimension for the point of being the most striking feature to the principles of New Urbanism. Table 2 illustrates the two main descriptive indicators of the behavioral dimension.

\begin{tabular}{|c|c|c|c|}
\hline & & $\begin{array}{l}\text { Copenhagen, } \\
1993\end{array}$ & $\begin{array}{l}\text { Adelaide, } \\
2002\end{array}$ \\
\hline 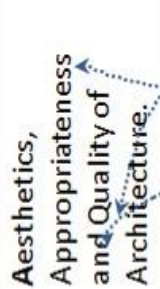 & $\begin{array}{l}\text { Quality } \\
\text { The economic health and } \\
\text { harmanious evolution of } \\
\text { neighborhopds; districts, and } \\
\text { corridors can be improved } \\
\text { through graphic urban design } \\
\text { coudes that serve as } \\
\text { predictable guides for } \\
\text { change, }\end{array}$ & $\begin{array}{l}\text { Quality Architecture \& Urban } \\
\text { Design (Aesthetics) } \\
\text { 19.Ensure that a. code of aesthetics } \\
\text { and esthetics standards, } \\
\text { 20 Foster the human comfort } \\
\text { 21.Create a sense of place; Special } \\
\text { placement of civic uses and sites } \\
\text { within community, }\end{array}$ & $\begin{array}{l}\text { Appropriateness } \\
\text { 22.Low level of noise and few } \\
\text { disturbances } \\
\text { 23.Intimate public spaces } \\
\text { 24.Fine views and good } \\
\text { details } \\
\text { 25.Interesting facades, } \\
\text { window displays and exhibits }\end{array}$ \\
\hline
\end{tabular}

Figure6: ThisRepresentsthe Interrelationbetween the TitleA with boththeCNU, Copenhagen and Adelaide Represented by a Dotted Line

(Source:Ibid)

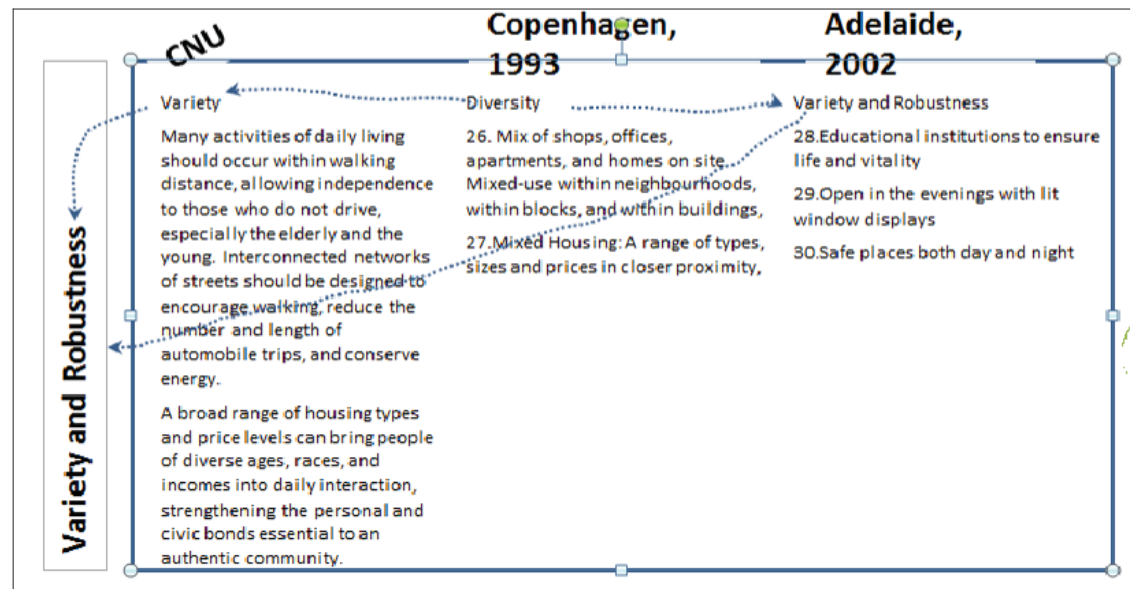

Figure 7: This Represents the Interrelation between the title $\mathrm{V}$ with both the $\mathrm{CNU}$, Copenhagen and Adelaide Represented by a Dotted Line (Source:Ibid) 


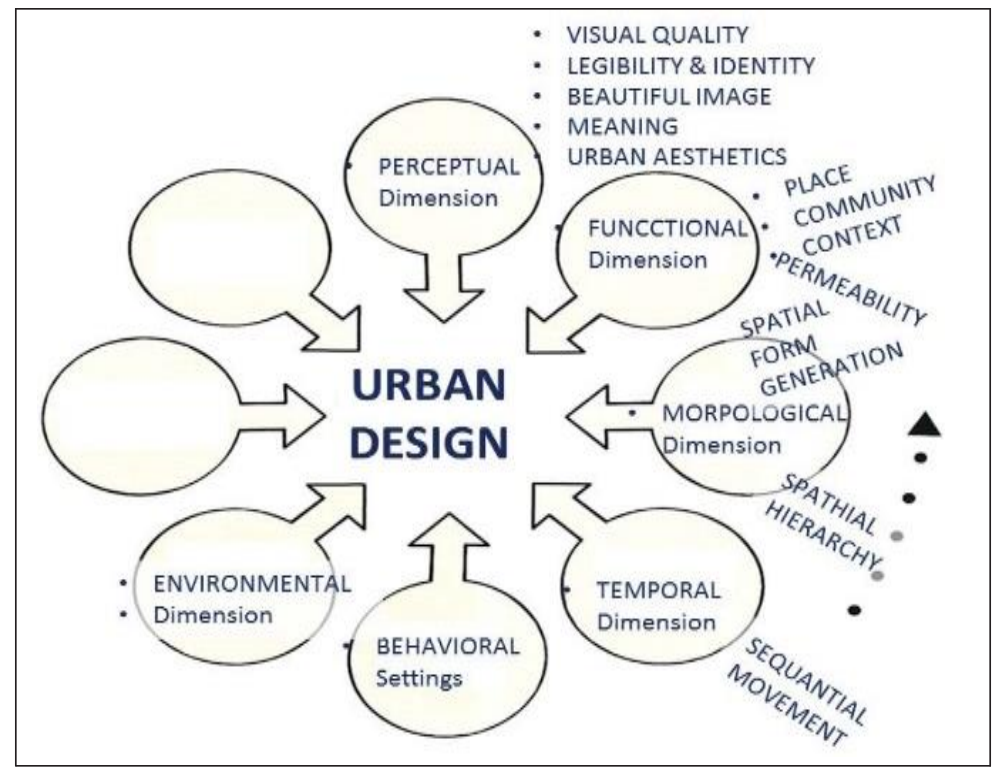

Figure 8: The Six Dimensions of Urban Design

Table 2: The Behavioral Dimension Includes Certain Sub Issues and Indicators

(Berison, 2008; llewelyn, 2010; Evans, 2012)

\subsection{Approach Apparatus}

The paper deals with New Urbanism principles in comparison with the one of the six urban design dimensions. Therefore, it assesses the principles of the mentioned theory on an Egyptian neighborhood. In addition, it extends to their relationship with the behavioral dimension. Thus, the paper formulates a matrix which called as "New Urbanism vs. Behavioral Dimension", Fig.9. ${ }^{*}$ This matrix tests the behavioral milieu and the principles of New Urbanism upon the case study. Since, it adapts an assumption which concedes that the behavioral dimension is the most adjacent to the theory (Dunham, 2000).

\subsection{The Survey}

The process of surveying aims at verifies the validity of the principles of New Urbanism in the Egypt. The field survey encompasses three main phases: appreciate the context, site survey and getting out the concluded remarks (table 2).

\footnotetext{
"The matrix has two main axes: New Urbanism principles and the general framework of the behavioral dimensions. Fig. 10 shows the principles, which conclude from Fig. 4, 5,6 and 7, list as thirty principles within four main axes. New Utbanism principles are in the vertical oolurmn and the behavioral dimensions the horizontal row. The results achieved from the analysis of a matix of relations between principles and dimensions ranging between high and low. The highest comes from high potentialities with low constrains; medum occurs from small potentialities with low constrains, and the lowest occures from small potentialities with high constrains. The mutual impact of the principles versus dimensions shows with dots, no joint impact shows by blanked cells. One issue is out of author specialization; the physiological abiities by blanked cells. One issue is out of author specialization; the physiological abilities (Fig. 10).
} 


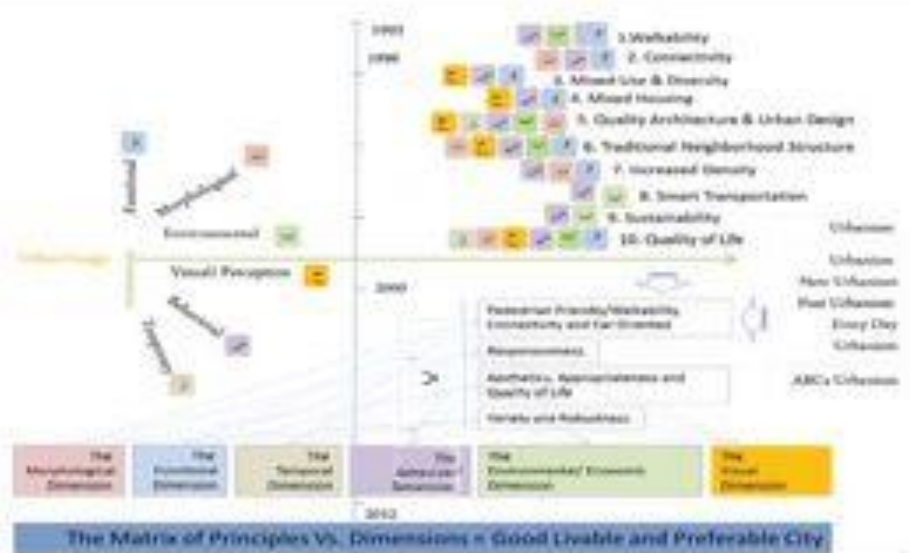

Figure9: TheRelationshipbetweentheUrbanDesignDimensionsandPrinciples of NewUrbanism. Itshons thattheBehavioral Dimensionisthe Most Connected to all New Urbanism Principles

Table 2: The Behavioral Dimension Includes Certain Sub Issues and Indicators (Berison, 2008; llewelyn, 2010; Evans, 2012)

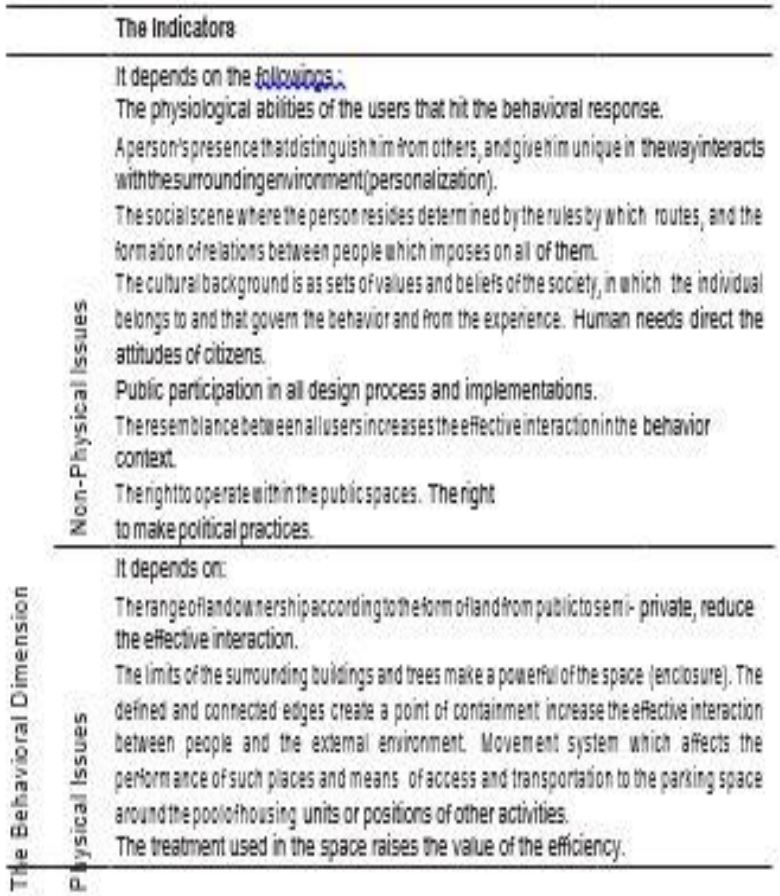


Elshater, A., / Asian Journal of Environment-Behaviour Studies (ajE-Bs), 3(8) May / Jun 2018 (p. 205-220)

\begin{tabular}{|c|c|c|c|c|c|c|c|c|c|c|c|c|c|c|}
\hline & & \multicolumn{13}{|c|}{ Dutniend D-wast } \\
\hline & & $\frac{3}{2}$ & $\frac{7}{8}$ & $\frac{8}{8}$ & $\frac{\frac{2}{5}}{\frac{2}{2}}$ & $\frac{5}{5}$ & $\frac{3}{\frac{3}{3}}$ & 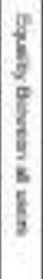 & 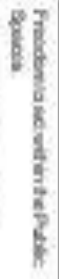 & $\begin{array}{l}3 \\
\frac{2}{2} \\
\frac{2}{8} \\
\frac{2}{8}\end{array}$ & $\begin{array}{l}\frac{7}{2} \\
\frac{g}{g} \\
\frac{3}{3}\end{array}$ & $\frac{9}{8}$ & $\frac{8}{8}$ & 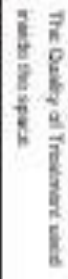 \\
\hline \multirow{14}{*}{ 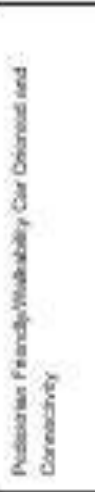 } & Proscia 1 & & & & $t$ & 1 & & & & 1 & & 1 & 1 & \\
\hline & Precion 2 & & & 1 & 1 & 1 & & & & 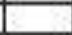 & & & 1 & \\
\hline & Prescas 3 & & & 1 & 1 & 1 & & & & 1 & 1 & & 1 & \\
\hline & Protich 4 & & & & & 1 & & & & & & & 1 & \\
\hline & Prascins & & & & & 1 & & & 1 & & & & 1 & \\
\hline & Arescich 8 & & & & 1 & 1 & & & 1 & & & 1 & & 1 \\
\hline & Precich 7 & & & 1 & 1 & 1 & & & 1 & & & & & \\
\hline & Prosich 8 & & & 1 & & 1 & & & 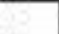 & & 7 & 1 & & 1 \\
\hline & Arrescos & & & 1 & & 1 & & 1 & 1 & & & & & 1 \\
\hline & Presich it & & & 1 & 1 & 1 & & & & & & 1 & 1 & 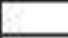 \\
\hline & Presch 11 & & 1 & 1 & 1 & 1 & & & & & & 1 & 1 & 1 \\
\hline & Aneticle 12 & & 1 & 1 & & 1 & & & & 1 & & 1 & & 1 \\
\hline & Pracicia 12 & & 1 & 1 & 1 & 1 & & & 1 & 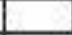 & & & & $t$ \\
\hline & Arnegin 14 & & 1 & 1 & & 1 & & & & 1 & & & & 1 \\
\hline \multirow{4}{*}{$\frac{3}{3} 3$} & Prosecta is & & 1 & 1 & 1 & 1 & & & & $\infty$ & & 1 & & \\
\hline & Prescib is & & 1 & 1 & 1 & 1 & & & 1 & 1 & & & & \\
\hline & Presicin 17 & & 1 & 1 & 1 & 1 & & & 1 & 1 & & & & \\
\hline & Arescia 1t & & 1 & 1 & 1 & 1 & & 1 & 1 & 1 & 1 & & 1 & \\
\hline \multirow{7}{*}{ 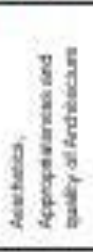 } & Prosicle if & & $\$$ & 1 & & & & & & & & 1 & & 1 \\
\hline & Prosignz & & 1 & 1 & 1 & $t$ & & & 1 & & & 1 & & 1 \\
\hline & Proscin il & & 1 & 1 & 1 & 1 & & & & & & 1 & & 1 \\
\hline & Presciv 21 & & 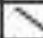 & 1 & & 1 & & & & & & & & 1 \\
\hline & Prosigin 22 & & 1 & 1 & 1 & 1 & & & 1 & & & & & \\
\hline & Prescio 24 & & 1 & 1 & 1 & 1 & & & 1 & & & 1 & & 1 \\
\hline & Prosches & & 1 & 1 & 1 & 1 & & & 1 & & & 1 & & 1 \\
\hline \multirow{5}{*}{ 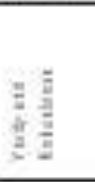 } & Prastion 28 & & & 1 & 1 & 1 & & 1 & 1 & & 1 & & & \\
\hline & Arnecia 7 & & & 1 & 1 & 1 & & $t$ & 1 & 1 & 1 & & & \\
\hline & Procenta & & & 1 & & & & & & & 1 & & & \\
\hline & Proscis 20 & & & 1 & 1 & & & & & & & & & \\
\hline & Prescie $x$ & & & 1 & 1 & 1 & & & 1 & 1 & 1 & & 1 & \\
\hline & 01 Uas & & & & & & & & & & slatas & $=500$ & tituter & \\
\hline
\end{tabular}

Figure 10: The Matrix "New Urbanism versus Behavioral Dimension" 


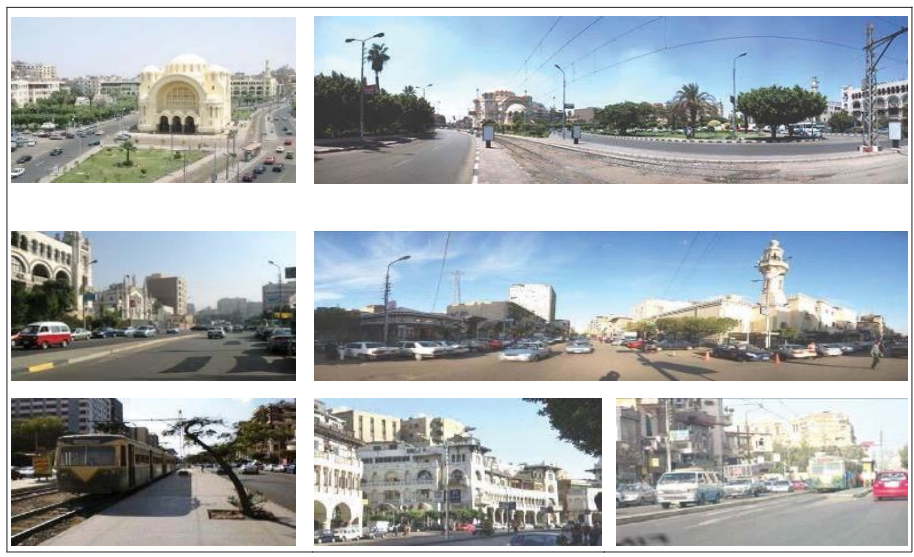

Figure 11: (a) The Basilica Church Plaza has the Dominance in the Site as a Landmark; (b) The Basilica Church appears from Al-Ahram Sreet;

(Source: Ibrahim Shewei);

(c) The Mode of Transportation passes by in Nazih Khalifa Street; (d) Haroon El-Rushed Street (source: Ibrahim Shewei); (e) The Metro line in El-Ahram Street; (f) Belgium Building Style;(g) Osman lan Affine Street

(Source: Third year students, Ain Shams University, 2011)

\subsection{Appreciate the Context}

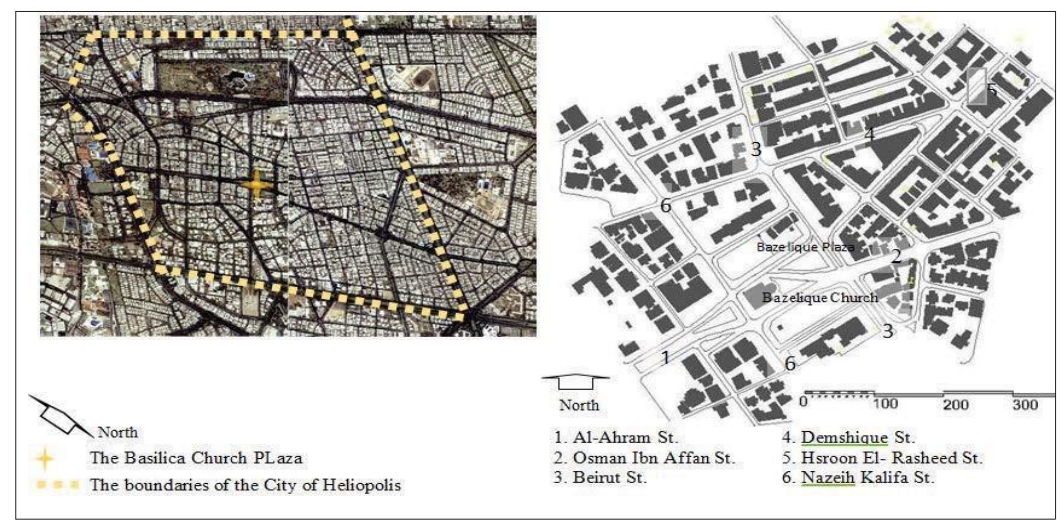

Figure 12: (a) The photo represents the city of Heliopolis,

(source: the author based on (Dobrowlska, 2006);

(b) shows the main feature in the study area

(source: author and Sara Noeir) 
The Basilica Church Plaza is the most predominance, Fig. 12, 13, functionally and visually, square in the city of Heliopolis. ${ }^{*}$ The choice of the Basilica Church Plaza, as a study area, is for its location as a focal point. It contains controversial elements of behavioral aspects, which could be analyzed from the perspective of PRAV. In addition to its location, the cohabitation field of the researcher makes exploring the site more reliable.

\subsection{The Survey Outcomes: Principles vs. Dimensions}

This section answers the following question "to what extent does the Basilica Church Plaza conforms to the PRAV?" Fig. 14, 15, 16, and 17 find out results horizontally and vertically using a quantitative analysis. From Fig. 15, the paper concludes some remarks. There is no correlation between New Urbanism and both the properties and the public participation. Vertically, the issues equal between all users; enclosureand transportation are taking a high percentage of grades. Consequently, it leads to the percentage of a weak equity among all users. The percentage of the grades that follow express of the enclosure, the movement system, and the right to act in the outdoor public spaces range from medium to high. Ultimately, the following three principles; 6 th, 9 th and 13 th received the highest percentage.

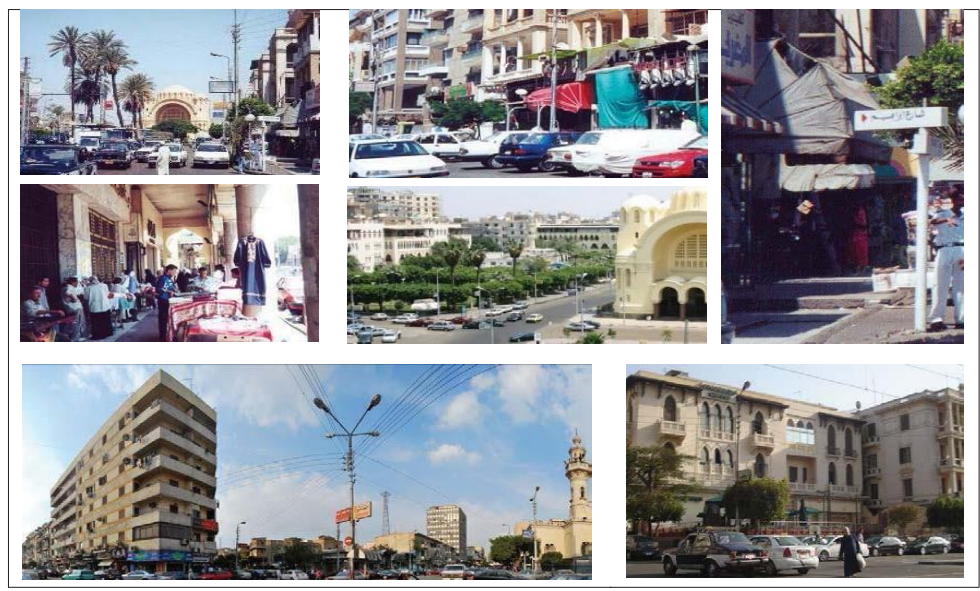

Figure 13: (a)Al-Ahram Street; (b)theoccupation ofsidewalksbyshopsextension and roadside parking;(c) bad treatment of sidewalk pavement; (c) The occupation of sidewalks by vendors (e) the greenery area nearby the BasilicaChurch surrounded byafence; notaccessibleand notused as outdoor space; (f) Medan

Egamaa district

(Source: Ibrahim Shewei);

(g) The unsafe pedestrian movement

(Source: third year students, Ain Shams University, 2011)

\footnotetext{
"The city of Heliopolis etablished in the frst decade of the previous century. The Egyptan government granted to Baron Empan a concession for the urbanization of af -72 desert hectares. He gave a behest to Gaspar, the architect, to plan a new community. The ancient Heliopois lies in the Cairo suburban of

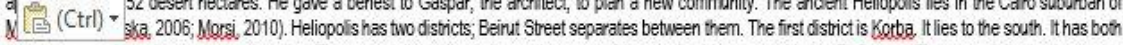
the average and the above-average housing. The second district lies in the northern part of the site. It addresses as Medan El-Gamaa. The second district devoted to economic housing and crafts areas. Baron Emoan derived the idea of electrical tram to develop remote areas and raise their value by Inking them to down town. The Basilica Church Plaza is in an intermediate zone between the two main districts, Kacha and Medan Egamaa.
} 
Furthermore, the last sub issues received a small percentage of the grade of the behavioral dimensions in comparison with the New Urbanism principles. Horizontally, the relationships between both 8th and 13th principles comparing with the behavioral settings receive a high percentage $(100 \%)$. The same as the previous step, the principles such as 4 th, 7 th, 12 th, and 14 th have $0 \%$ in with the behavioral issues. Therefore, these mentioned principles should have priority in redesigning process; especially, they have the highest achievements in the study area.

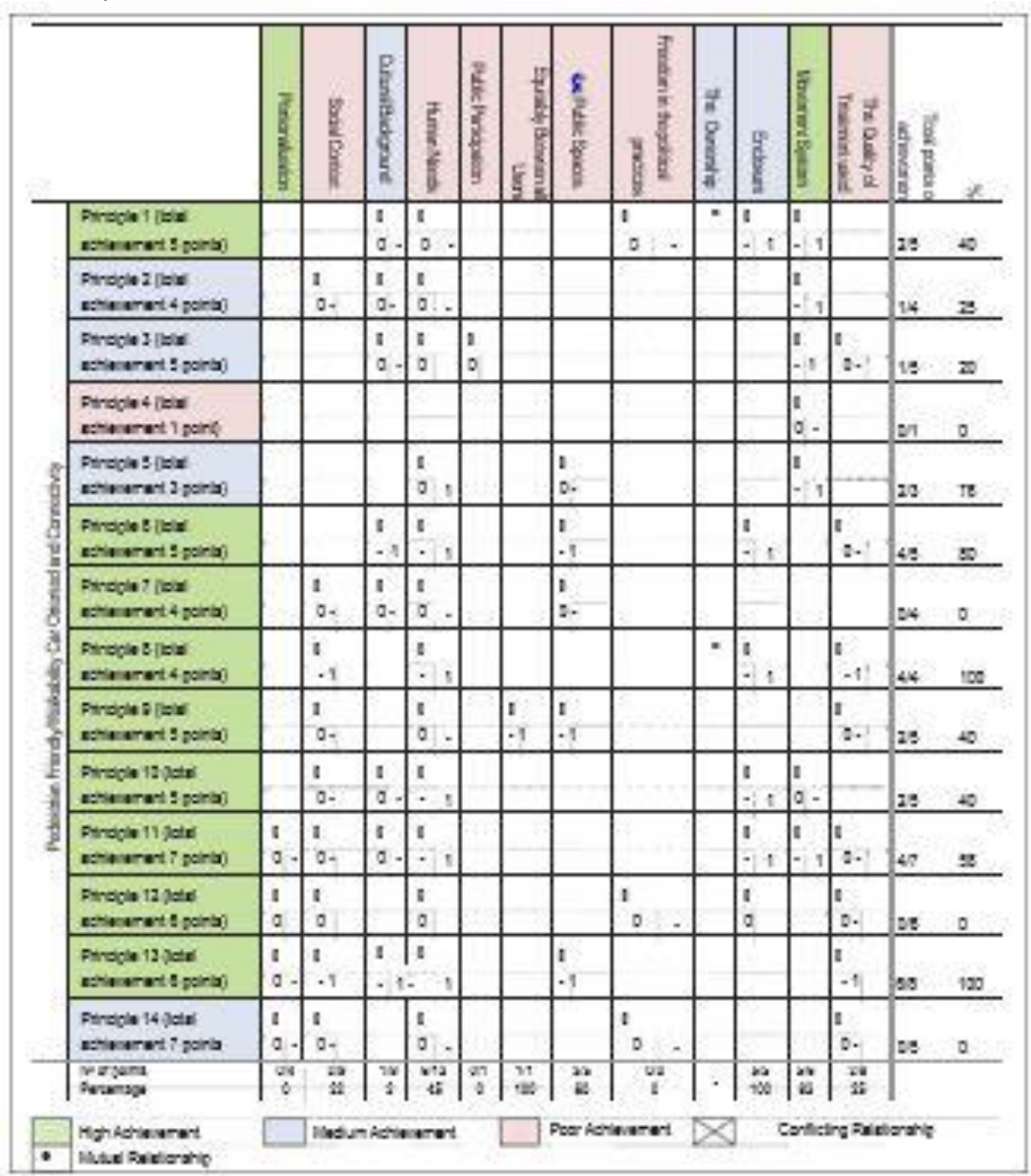

Figure 14: ThisAddressthePrinciplePversustheBehavioral Dimensions

From Fig. 15, the matrix finds out some notes vertically and horizontally. Vertically, the public participation has no effect to the principles of the New Urbanism. The social context, cultural background and the ownership achieve $0 \%$ of the number of relations 
between them and the principles of the New Urbanism. This percent is detectable with a serious issue which is achieving the responsiveness. Bad responsiveness may affect negatively on achieving the New Urbanism principles. The freedom to act within the Public spaces, the ownership and the quality of treatment has a high ratio (100\%) on the responsiveness quality. Horizontally, all principles, except principle 17 , have a poor relationship with the behavioral dimension. Principle 17 has no feedback on this matter.

Fig. 16 indicates some regards vertically and horizontally. Vertically, there is no correlation of the New Urbanism principles with the issues of public participation, ownership, and freedom in the political practices. The low percentage of the total number of relationships between the issues of personalization, social context, cultural background, human needs, and quality of treatment inside the space achieve with the New Urbanism principles. In spite of, the percentage of the most of the issues include strong impacts on the site. Medium percentage ( 50 and $60 \%$ ) of the total number of relationships between the issues of the freedom to act within the public spaces and enclosure with the New Urbanism principles. Horizontally, a poor percentage of the behavioral milieu with the principles 20,21 and 22. In spite of, the percentage of most of the principles before being poor, the principles 22 and 23 have medium impacts on the site. High percentage (85\%) of the total number of relationships between the principles 24 and 25 with the behavioral milieu. Previously, the above provides a future vision to the urban designer to increase the values of the site. It provides a significant importance for testing and developing the matrix. That refers to the importance of the strengthening of the correlation between the New Urbanism principles and the urban design dimensions.

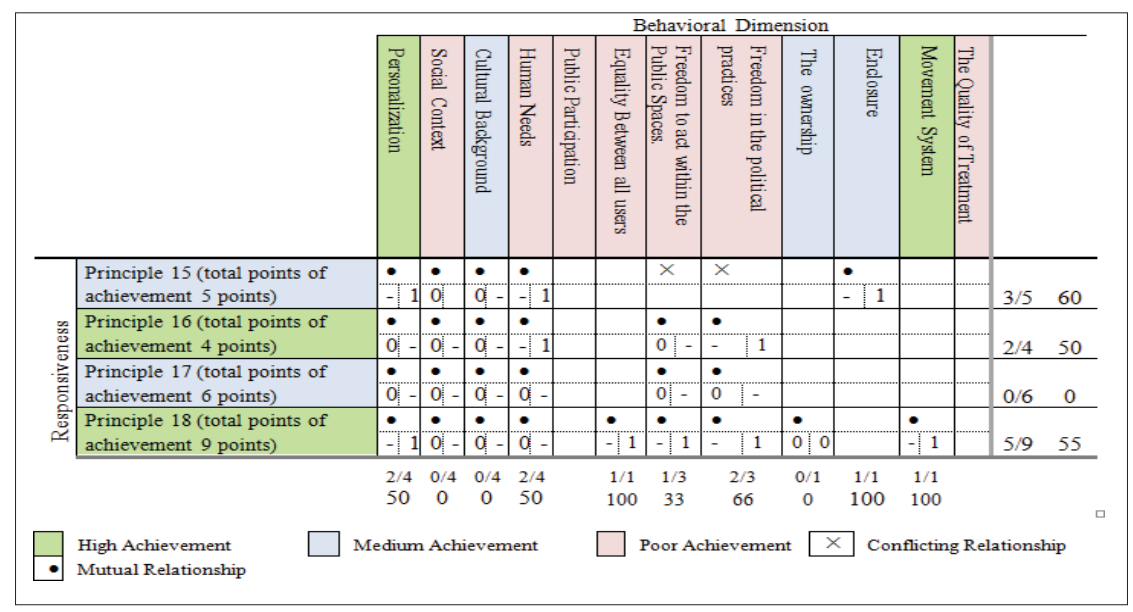

Figure 15: This Addresses the Matrix "Responsiveness versus Behavioral Dimension"

From Fig. 17, the matrix finds out some notes vertically and horizontally. Vertically, there is no any correlation between the public participation and New Urbanism principles. The 
issues of social context, cultural background, human needs, the freedom to act within the public spaces and ownership obtain the percentage between $80-100 \%$ of the total percentage of the relationships between the previous dimensions and New Urbanism principles.

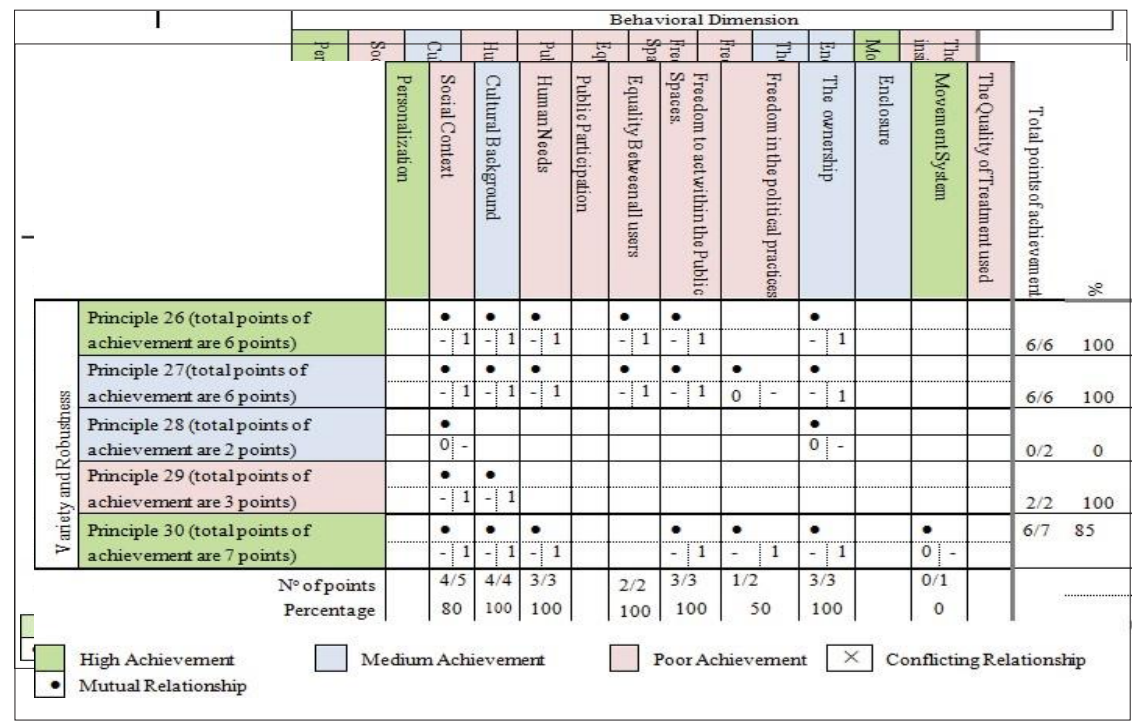

Figure 16: This Addresses the Matrix "A versus Behavioral Dimension" Figure 17: This Addresses the Matrix ' $V$ ' versus Behavioral Dimension

Therefore, the principles 30 should take into account the political issues in Cairo. Horizontally, the percentage of the principles of variety and robustness in its relationships with the behavioral dimensions ranging between $80-100 \%$. As well as, the principle 28 in its relationships with the issues human need and movement system has not taken any percentage.

\subsection{Conclusion}

This paper tried to find out the relationship between the principles of New Urbanism with one of the urban design dimensions. This was under a certain hypothesis. The hypothesis will be true if taken into account the following notes. First, the public participation can play a role in motivating the principles and dimensions, towards a real application. For examples, although the New Urbanism called for bicycle as a clean transportation, some communities are against the idea. Second, the principles of New Urbanism should respect the cultural context of the certain context. Third, the percentage of the mutual impact between the principles and the dimensions numerically needs to be done by a digital model.

Current work followed the inductive analytically and an empirically approaches. The first focused on the quantitative analysis whereas a case study analysis depends on the 
results of the previous quantitative; by using the matrix that combines the principles of New Urbanism versus the human behavioral dimension. The second was the introducing the principles of New Urbanism in a comparative way with the urban design dimensions. The paper designed, for this purpose, a matrix which addressed as the principles of New Urbanism versus the behavioral dimension. In addition to, the matrix verified the validity of the principles of New Urbanism versus the dimensions of urban design in an Egyptian neighborhood unit, taking into account the of the urban design dimensions to accommodate the change in the human needs and rights.

The paper proposes future researches as improve the proposed integrated approach, evaluate a matrix that addressed the role of all urban design dimensions related to the New Urbanism principles, and provide expanded the matrix to cover all the Urbanism principles that exist within the urban design dimensions. In addition to, the PRAV may play a role in the constructive integration within neighborhood units inside the smaller Arab communities than Cairo.

\section{References}

Berison, B. (2008). Human Behavior. New York: Brase World Press. Carmona, M. T. (2010). Public Places-Uraban Spaces: The dimensions of Urabn Design. New York: Architecture Press.

Congress of New Urbanism, (1996). Charter of The New Urbinism. New York: Mc Grew-Hil.

Desy, C. a. (1990). Designing Places for People. New York: a hand book on Human Behavior for Architects Designer.

Dobrowlska, A. a. (2006). Heliopolis: Rebirth of the City of the Sun. Cairo: The American University in Cairo Press.

Duany, A. E.-Z. (2001). Suburban Nation: The Rise of Sprawl and the Decline of the American Dream. San Francisco: North Point Press.

Evans, R. (2012). Developing Quality Places: Urabn Design Compendium 2. London: English Partnerships \& the Housing Corporation.

Gehl, J. (2002). Public Spaces and Public Life: city of Adelaide:2002. Adelaide: South Australain Government: Planning SA.

Grava, S. (2004). Urban Transportation System: Choices For Comunnities.McGraw-Hill.

Illbert, R. (1981). Heliopolis: Le Caire 1905-1922. Paris: Centre National de la Recharch Scientifiue.

Ilewelyn, D. (2010). Urban Design Compendium. London: English Partnerships, The Housing Corporation.

Kelbaugh, D. (2001). Three Urbanisms and the Public Realm. 3rd International Space Syntax Symposium, (p. 14). Atlanta. Krier, R. (1997). Urban Space. London: Academy Edition.

Krier, R. (2009). The Architecture of Community. Washington DC.: Island Press.

McCluskey, J. (1992). Road Form and Townscape. Butterworth-Heinemann. Morsi, M. (2010). Heritage: Saving 
Elshater, A., / Asian Journal of Environment-Behaviour Studies (ajE-Bs), 3(8) May / Jun 2018 (p. 205-220)

Heliopolis? Al-Ahram Weekly Online. Panerai, P. C. (2004). Urban Form: The Death and Life of the Urban Block. London: Architectural Press.

Steuteviller, R. P. (2009). New Urbanism: Best Practices Guide. The online version on http://www.newurbanism.org/newsreports.html:NewUrban News.

Taarup, K. F. (2000). The Charter. Retrieved 8 5, 2012, from www. copenhagencharter.com: http://www.copenhagencharter.com/ TheCharter.pdf

U. N Programme,. (2009). Planning Sustainable Cities: Policy Directions: Global Report on Human Settlements 2009. London: UN- Habitat. 